Hydrology and Earth System Sciences, 9, 57-66, 2005

www.copernicus.org/EGU/hess/hess/9/57/

SRef-ID: 1607-7938/hess/2005-9-57

European Geosciences Union

\title{
Biogeochemistry of the Kem' River estuary, White Sea (Russia)
}

\author{
V. P. Shevchenko ${ }^{1}$, Y. S. Dolotov ${ }^{2}$, N. N. Filatov ${ }^{3}$, T. N. Alexeeva ${ }^{1}$, A. S. Filippov ${ }^{1}$, E.-M. Nöthig ${ }^{4}$, A. N. Novigatsky ${ }^{1}$, \\ L. A. Pautova ${ }^{1}$, A. V. Platonov ${ }^{3}$, N. V. Politova ${ }^{1}$, T. N. Rat'kova ${ }^{1}$, and R. Stein ${ }^{4}$ \\ ${ }^{1}$ P. P. Shirshov Inst. of Oceanology of the Russian Academy of Sciences, Nakhimovsky prospect, 36, Moscow 117997, Russia \\ ${ }^{2}$ Water Problems Institute of the Russian Academy of Sciences, Gubkina street, 3, Moscow 119991, Russia \\ ${ }^{3}$ Northern Water Problems Ins. KRC RAS, Prospekt Alexandra Nevskogo, 50, Petrozavodsk 185003, Rep. of Karelia, Russia \\ ${ }^{4}$ Alfred Wegener Institute for Polar and Marine Research, Columbusstrasse, Bremerhaven 27568, Germany
}

Received: 20 October 2004 - Published in Hydrology and Earth System Sciences Discussions: -

Revised: 15 May 2005 - Accepted: 1 June 2005 - Published: 14 June 2005

\begin{abstract}
The biogeochemistry of the river-sea interface was studied in the Kem' River (the largest river flowing to the White Sea from Karelian coast) estuary and adjacent area of the White Sea onboard the RV "Ekolog" in summer 2001, 2002 and 2003. The study area can be divided into 3 zones: $\mathrm{I}$ - the estuary itself, with water depth from 1 to $5 \mathrm{~m}$ and low salinity in the surface layer (salinity is lower than $0.2 \mathrm{psu}$ in the Kem' River and varies from 15 to $20 \mathrm{psu}$ in outer part of this zone); II - the intermediate zone with depths from 5 to $10 \mathrm{~m}$ and salinity at the surface from 16 to $22 \mathrm{psu}$; III the marine zone with depths from 10 to $29 \mathrm{~m}$ and salinity 21-24.5 psu. Highest concentrations of the suspended particulate matter (SPM) were registered in the Kem' mouth (5$7 \mathrm{mg} / \mathrm{l}$ ). They sharply decreased to values $<1 \mathrm{mg} / \mathrm{l}$ towards the sea. At beginning of July 2001, particulate organic carbon (POC) concentration in the river mouth was $404 \mu \mathrm{g} / \mathrm{l}$ and POC content in total SPM was 5.64\%. In the marine part of the studied area the POC concentration varied from 132 to $274 \mu \mathrm{g} / 1$ and the POC contents in suspended matter increased to $19-52.6 \%$. These studies show, that the majority of riverborne suspended matter in the Kem' estuary deposits near the river mouth within the 20 psu isohaline, where sedimentation of the suspended matter takes place. The role of freshwater phytoplankton species decreases and the role of marine species increases from the river to sea and the percentage of green algae decreases and the role of diatoms increases. The organic carbon $\left(\mathrm{C}_{\text {org }}\right)$ to nitrogen $(\mathrm{N})$ ratio $\left(\mathrm{C}_{\text {org }} / \mathrm{N}\right)$ in both suspended matter and bottom sediments decreases from the river to the marine part of the mixing zone (from 8.5 to 6.1 in the suspended matter and from 14.6 to 7.5 in the bottom sediments), demonstrating that content of terrestrial-derived organic matter decreases and content of marine organic matter
\end{abstract}

Correspondence to: V. P. Shevchenko

(vshevch@geo.sio.rssi.ru) increases from the river mouth to the sea. The Kem' estuary exhibits a similar character of biogeochemial processes as in the large Arctic estuaries, but the scale of these processes (amount of river input of SPM, POC, area of estuaries) is different.

\section{Introduction}

Study of biogeochemical processes in estuaries is of particular significance in understanding their role in global cycles of carbon and many other chemical elements. Estuaries are complex mixing zones displaying several interrelated physical, chemical or biological interfaces, where biogeochemical processes significantly affect the fate of riverborne material (Kemp et al., 1982; Relexans et al., 1988; Fichez et al., 1993). Over the past few decades, in many countries, particular attention has been paid to the study of estuaries, first due to the fact that various pollutants supplied by the riverine runoff accumulate there, and at the same time they are characterized by high biological productivity (Sholkovitz, 1976; Joint and Pomroy, 1981; Martin and Windom, 1991; Martin et al., 1993; Khlebovich et al., 1997; Schäfer et al., 2002). Most of the suspended matter is trapped in the estuaries where freshwater and salt water mixes (salinity of about 2 to $15 \mathrm{psu}$ ) and accumulation (precipitation) of fine-grained suspension occurs due to coagulation processes (Lisitsyn, 1995). More than 90\% of the suspended matter (including particulate organic carbon) probably accumulates within this so-called "marginal filter" (Lisitsyn, 1995). In the marginal filter, the following processes act in sequence from the river to the sea: gravitational sedimentation, physico-chemical processes in colloid system (coagulation and flocculation, formation of sorbents), and, finally,

(C) 2005 Author(s). This work is licensed under a Creative Commons License. 


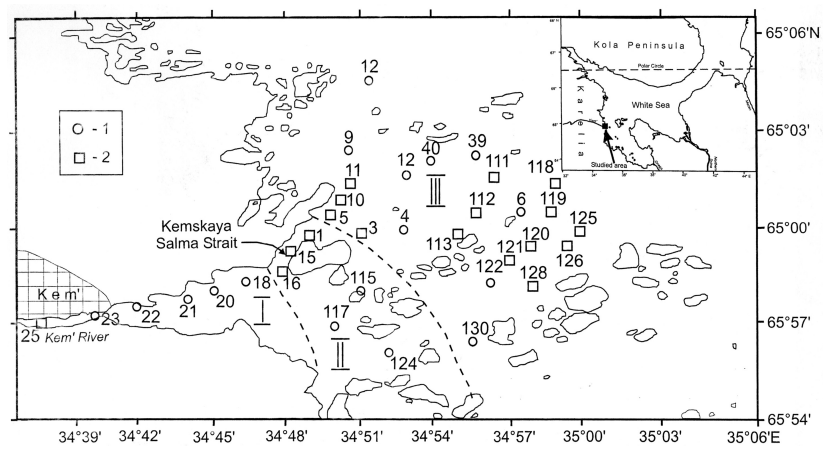

Fig. 1. Position of sampling sites in the Kem' estuary and the adjacent White Sea (I - the estuary itself; II - the intermediate zone; III - the marine zone): 1 - suspended matter samples; 2 - suspended matter and bottom sediments samples.

biological processes (growth of phytoplankton with conversion of dissolved elements to biogenic suspended matter and the process of biofiltration). Flocculation of dissolved organic and inorganic matter during the mixing of river and sea water is an important removal mechanism for $\mathrm{Fe}, \mathrm{Mn}, \mathrm{Al}$, P, organic carbon and humic substances (Sholkovitz, 1976). From this point of view rivers flowing into the White Sea, Russia and their estuaries have not been studied (Berger et al., 2001; Lisitzin, 2003). Here we report the biogeochemistry of the river-sea interface in the Kem' River estuary and adjacent area of the White Sea (Fig. 1) in summer 2001, 2002 and 2003. These studies were carried out in the framework of "White Sea System" project, a subproject of LOIRA (LandOcean Interactions in the Russian Arctic) (Dolotov et al., 2002a, 2004, 2005; Lisitzin, 2003; IASC, 2004; Lisitzin et al., 2004).

Kem' is the largest river flowing to the White Sea from the Karelian coast. The length of the Kem' is $194 \mathrm{~km}$, its catchment area is $28000 \mathrm{~km}^{2}$ and the annual discharge is about $8.5 \mathrm{~km}^{3}$ (in average $270 \mathrm{~m}^{3} / \mathrm{s}$ ) (Vodogretzkii, 1972). The catchment of the Kem', located in the crystalline Baltic Shield, consists of gneisses and amphibolites (Sviridenko, 1980; Volodichev, 1990). The majority of the Kem' basin is covered by taiga. The small city of Kem' (17400 inhabitants) is situated in the lower part of the river (Nemkovich and Katmazin, 1999). Mans impact in the study area is very small and the Kem' river-estuary could be described as pristine (Dolotov et al., 2002a).

Kem' River fresh water discharge to the White Sea is highly seasonal with the main portion occurring during spring and summer (Fig. 2). The Kem' estuary is ice-covered from December to April (Glukhovsky, 1991).

According to results of multidisciplinary studies in the Kem' estuary and the adjacent part of Onega Bay (Dolotov et al., 2002a, 2004, 2005) the study area can be divided into 3 zones (Fig. 1): I - the estuary itself, with water depth from 1 to $5 \mathrm{~m}$ and low salinity in the surface layer (salinity

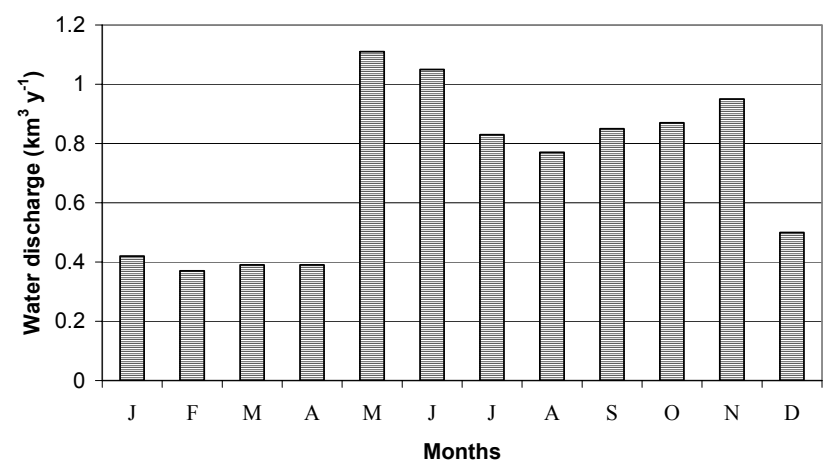

Fig. 2. Seasonal variations in water discharge of the Kem'. The monthly discharge data are taken from the (Leonov and Chicherina, 2004) and represent the average multi-year discharges.

at St. 25 and 23 is lower than 0.2 psu and in outer part of this zone varies from 15 to $20 \mathrm{psu}$ ); II - the intermediate zone with depths from 5 to $10 \mathrm{~m}$ and salinity at the surface from 16 to $22 \mathrm{psu}$; III - the marine zone with depths from 10 to $29 \mathrm{~m}$ and salinity $21-24.5 \mathrm{psu}$. Tides in the Kem' estuary are semi-diurnal. In summer the tidal range in the estuary varies between 0.5 and $1 \mathrm{~m}$ (Dolotov et al., 2004).

\section{Materials and methods}

Biogeochemical studies in the Kem' River estuary and adjacent part of the White Sea were carried out in 3 expeditions onboard the RV "Ekolog" in July 2001, August 2002 and July 2003. The position of stations (sampling sites) is shown in Fig. 1. Temperature and salinity at the stations were measured by calibrated "Quanta" CTD probe, results of these measurements are presented elsewhere (Dolotov et al., 2002a, 2004, 2005).

Water samples were obtained from the water column by Niskin bottles and from the surface by plastic bucket. The filtration of each water sample was carried out in all 3 expeditions through 3 parallel pre-weighted Nuclepore filters $47 \mathrm{~mm}$ in diameter (pore size $0.45 \mu \mathrm{m}$ ) and in July 2001 through 1 precombusted $\left(5 \mathrm{~h}\right.$ at $\left.500^{\circ} \mathrm{C}\right)$ Whatman $\mathrm{GF} / \mathrm{F}$ glass fiber filter. 0.3 to 2.51 of water were filtered through each $\mathrm{Nu}$ clepore filter and 1 to 41 of water were filtered through each Whatman GF/F glass fiber filter. After filtration filters were washed with distilled water and dried at $50-55^{\circ} \mathrm{C}$, packed in plastic Petry diches and then sealed in plastic envelopes for later analyses in the land laboratory. The Nuclepore filters were air-dried and re-weighed upon return to the laboratory, and these data were used to determine the dry mass of the suspended particulate matter (SPM) and to calculate the SPM concentrations. In more detail working procedures are described elsewhere (Lisitzin et al., 2003; Lukashin et al., 2003b). For phytoplankton studies $100 \mathrm{ml}$ of water from the sample were preserved with a glutaraldehyde-Lugol solution 


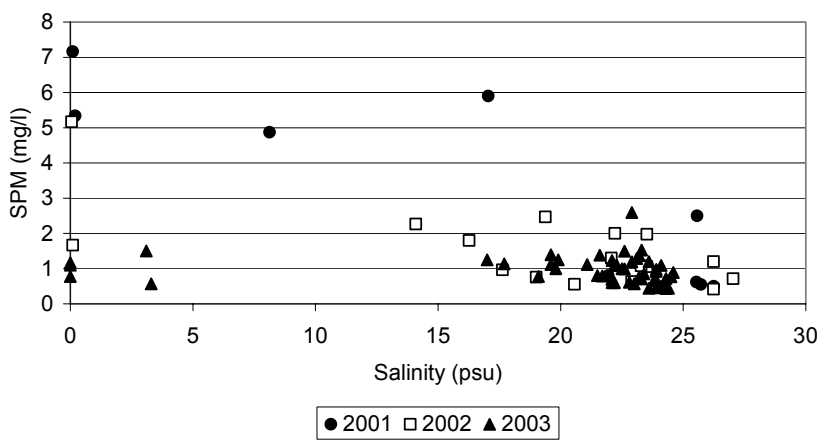

Fig. 3. SPM concentration vs salinity in surface layer of Kem' mixing zone in July 2001, August 2002 and July 2003.

(Rousseau et al., 1990). Surface bottom sediments were collected by $0.1 \mathrm{~m}^{2}$ van Veen grab. Coordinates of sediment sampling stations and water depth are presented in Table 1.

Grain size analysis of bottom sediments was carried-out by a water-mechanical method (Petelin, 1967). Organic carbon and nitrogen in suspended particulate matter were measured using a Carlo Erba-1500 analyzer, after subjection to $\mathrm{HCl}$ treatment to remove carbonates. Blank filters were run and the carbon and nitrogen values are blank-corrected. In bottom sediments total carbon and nitrogen were measured on LECO CN-2000 elemental analyzer. Organic carbon $\left(\mathrm{C}_{\text {org }}\right)$ has been determined using LECO CS-125 analyzer after acidification by $\mathrm{HCl}$. National Institute of Standards and Technology (NIST) standard reference material NIST RM 8704 was used to check the accuracy of the total carbon and organic carbon determinations. Scanning electron microscopy was carried out on a JSM-U3 microscope.

The biovolume of algae and protozoans cells was calculated from the volumes of appropriate stereometrical bodies (Smayda, 1978). The carbon content was estimated according to the method of Menden-Deuer and Lessard (2000).

\section{Results and discussion}

At beginning of July 2001 the highest SPM concentrations (5-7 mg/l) were registered at the mouth of the Kem', at St. 23 and 25. These values are higher than the SPM concentrations in the mouth of Keret' River flowing to the White Sea in the northern part of the Karelian coast, in September 2000 (Dolotov et al., 2002b), but lower than in estuaries of large Siberian rivers during the same season (Shevchenko et al., 1996; Lukashin et al., 1999; Rachold and Hubberten, 1999; Lisitsyn et al., 2000; Gebhardt et al., 2004). Such low SPM concentrations in the Kem' River mouth could be the result of a low weathering rate of hard crystalline rocks in the catchment area of the Kem' (Sviridenko, 1980; Volodichev, 1990). SPM concentrations decreased sharply to values $<1 \mathrm{mg} / \mathrm{l}$ towards the sea as the salinity increased (Fig. 3). At the end of August 2002, SPM concentrations decreased from $5.17 \mathrm{mg} / 1$

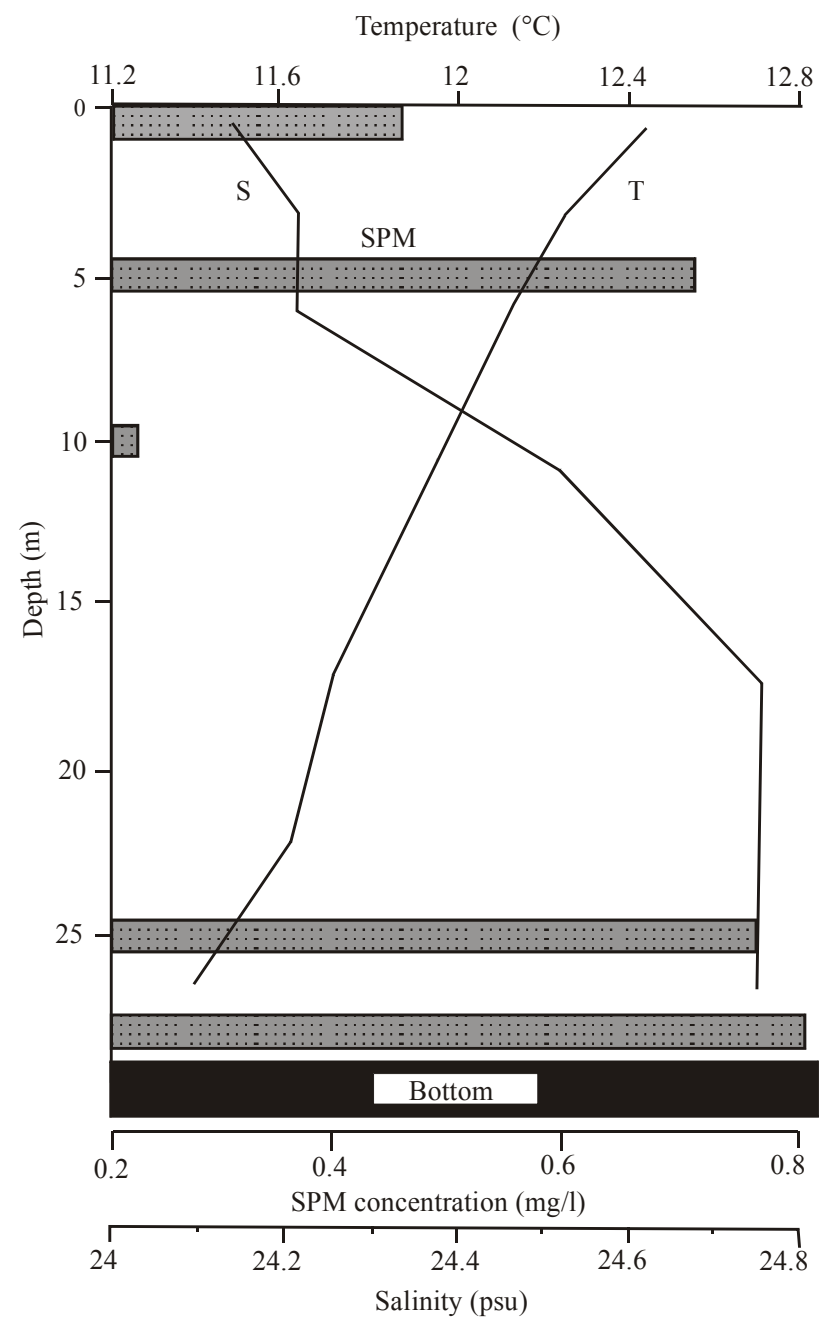

Fig. 4. Vertical distribution of temperature, salinity, SPM concentration at the Station 39 on August 27, 2002.

in the river mouth (St. 25) to $0.42-1.20 \mathrm{mg} / \mathrm{l}$ in the marine part of the mixing zone (St. 39 and 40). At the end of July and beginning of August 2003, SPM concentrations in the Kem' were very low $(0.77-1.17 \mathrm{mg} / \mathrm{l})$ due to unusually low atmospheric precipitation rates in July and at beginning of August 2003 (Parshina, 2003; Zakharenkova and Parshina, 2003). The distribution of SPM in the surface layer was irregular. In general, there was no strong decrease in SPM concentrations from the river to the sea. The SPM concentrations during ebb tides were higher, than during flood tides at the same stations. This difference between the SPM concentrations during ebb and flood tides is caused by different current velocities and by the input of riverine terrigenic material during the ebb. In the Kem' estuary, the absolute values of the current velocity during the ebb were greater than during the flood (Dolotov et al., 2002a, 2004).

The vertical distribution of suspended matter in the outer part of the estuary and the adjacent sea is characterized 
Table 1. Date of sampling, position of stations, water depth, percentage of fraction of sediments $<1 \mu \mathrm{m}$ and $<50 \mu \mathrm{m}$ and total carbon $\left(\mathrm{C}_{\text {total }}\right)$, organic carbon $\left(\mathrm{C}_{\text {org }}\right)$ and total nitrogen $(\mathrm{N})$ contents and $\mathrm{C}_{\text {org }} / \mathrm{N}$ ratios in surface sediments $(0-3 \mathrm{~cm})$ in the Kem' estuarine zone.

\begin{tabular}{cccccccccccc}
\hline Station & Date & Latitude $(\mathrm{N})$ & Longitude $(\mathrm{E})$ & Depth $(\mathrm{m})$ & $<1 \mu \mathrm{m}(\%)$ & $<50 \mu \mathrm{m}(\%)$ & $\mathrm{C}_{\text {total }}(\%)$ & $\mathrm{C}_{\text {org }}(\%)$ & $\mathrm{N}(\%)$ & $\mathrm{C}_{\text {org }} / \mathrm{N}$ \\
\hline 1 & 06.07 .2001 & $65^{\circ} 00.21^{\prime}$ & $34^{\circ} 49.46^{\prime}$ & 8 & 32.81 & 67.39 & 2.43 & 2.04 & 0.222 & 9.2 \\
5 & 05.07 .2001 & $65^{\circ} 00.50^{\prime}$ & $34^{\circ} 49.88^{\prime}$ & 9 & 13.69 & 37.62 & 1.46 & 1.29 & 0.129 & 10.0 \\
10 & 04.07 .2001 & $65^{\circ} 01.22^{\prime}$ & $34^{\circ} 50.15^{\prime}$ & 10 & 14.87 & 27.41 & 0.70 & 0.54 & 0.066 & 8.1 \\
11 & 04.07 .2001 & $65^{\circ} 01.49^{\prime}$ & $34^{\circ} 50.52^{\prime}$ & 13 & 0.44 & 1.53 & 0.27 & 0.13 & 0.020 & 6.2 \\
15 & 05.07 .2001 & $64^{\circ} 59.38^{\prime}$ & $34^{\circ} 48.13^{\prime}$ & 11 & 1.11 & 3.15 & 0.42 & 0.29 & 0.031 & 9.4 \\
16 & 06.07 .2001 & $64^{\circ} 58.65^{\prime}$ & $34^{\circ} 47.84^{\prime}$ & 6 & 1.38 & 12.77 & 0.84 & 0.58 & 0.063 & 9.2 \\
25 & 06.07 .2001 & $64^{\circ} 56.99^{\prime}$ & $34^{\circ} 37.91^{\prime}$ & 2 & 3.13 & 6.02 & 0.17 & 0.13 & 0.009 & 14.6 \\
111 & 02.08 .2003 & $65^{\circ} 01.62^{\prime}$ & $34^{\circ} 56.33^{\prime}$ & 24 & 6.24 & 19.71 & 0.73 & 0.23 & 0.049 & 4.6 \\
112 & 02.08 .2003 & $65^{\circ} 00.49^{\prime}$ & $34^{\circ} 55.51^{\prime}$ & 16 & 7.33 & 25.17 & 0.53 & 0.40 & 0.058 & 6.8 \\
113 & 02.08 .2003 & $64^{\circ} 59.84^{\prime}$ & $34^{\circ} 54.83^{\prime}$ & 16 & 44.87 & 81.59 & 1.99 & 1.66 & 0.212 & 7.8 \\
118 & 02.08 .2003 & $65^{\circ} 01.39^{\prime}$ & $34^{\circ} 58.75^{\prime}$ & 16 & 3.07 & 12.45 & 0.33 & 0.24 & 0.031 & 7.8 \\
119 & 02.08 .2003 & $65^{\circ} 00.52^{\prime}$ & $34^{\circ} 58.62^{\prime}$ & 18 & 3.23 & 14.21 & 0.51 & 0.38 & 0.049 & 7.7 \\
120 & 02.08 .2003 & $64^{\circ} 59.44^{\prime}$ & $34^{\circ} 57.87^{\prime}$ & 14 & 30.16 & 64.97 & 0.48 & 0.30 & 0.049 & 6.1 \\
121 & 02.08 .2003 & $64^{\circ} 59.02^{\prime}$ & $34^{\circ} 57.02^{\prime}$ & 23 & 1.21 & 14.45 & 0.057 & 0.55 & 0.065 & 8.4 \\
125 & 03.08 .2003 & $64^{\circ} 59.93^{\prime}$ & $34^{\circ} 59.77^{\prime}$ & 23 & 6.44 & 18.06 & 0.49 & 0.39 & 0.050 & 7.7 \\
126 & 03.08 .2003 & $64^{\circ} 59.49^{\prime}$ & $34^{\circ} 59.32^{\prime}$ & 18 & 3 & 19.33 & 0.61 & 0.41 & 0.061 & 6.7 \\
128 & 03.08 .2003 & $64^{\circ} 58.18^{\prime}$ & $34^{\circ} 57.94^{\prime}$ & 17 & 16 & 47.8 & 1.30 & 1.15 & 0.148 & 7.8 \\
\hline
\end{tabular}

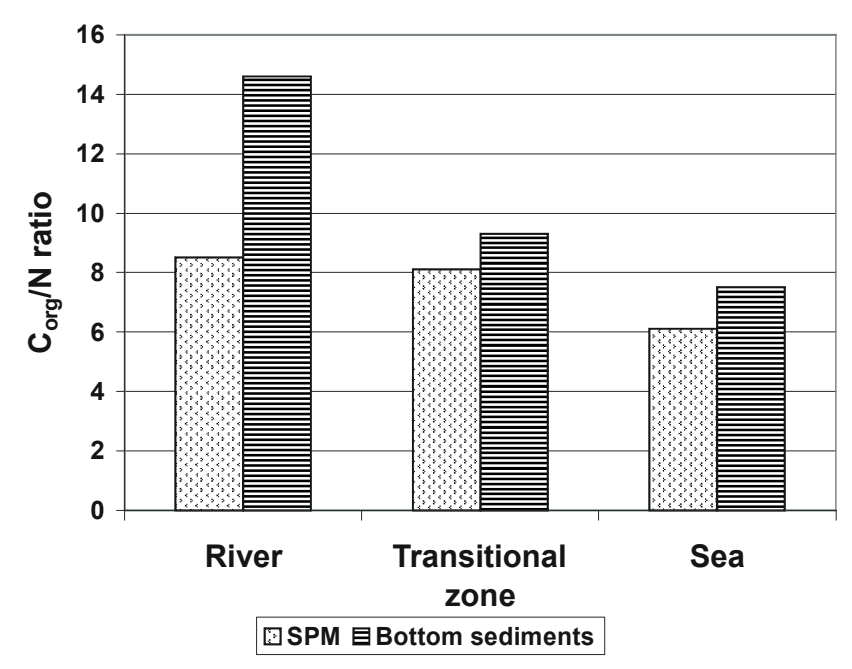

Fig. 5. $\mathrm{C}_{\text {org }} / \mathrm{N}$ ratio in SPM and bottom sediments.

by a pronounced three-layer structure with two maxima in suspended matter concentrations (Fig. 4): at the picnocline and near the bottom (nepheloid layer). The increase of SPM concentrations in the nepheloid layer is caused by resuspension of bottom sediments by tidal currents. This vertical distribution of SPM is similar to that described in the White Sea and other Arctic seas (Lisitzin et al., 2000, 2003). In the intermediate zone at St. 15 and 16 the near-bottom nepheloid layer was not registered.

At beginning of July 2001, particulate organic carbon (POC) concentration in the river mouth at St. 25 was $404 \mu \mathrm{g} / 1$ and POC content in total SPM was 5.64\% (Table 2). In the marine part of the marginal filter at Stations 5, 11 and 12 the POC concentration varied from 132 to $274 \mu \mathrm{g} / \mathrm{l}$ and the POC contents in suspended matter increased to $19-52.6 \%$. The results of scanning electron microscopy of SPM showed that at stations 25 and 23 mineral particles with sizes 1$10 \mu \mathrm{m}$ dominated and the content of diatoms was $5-10 \%$ from the total number of particles larger than $1 \mu \mathrm{m}$. Towards the sea, the percentage of mineral particle number decreased and the role of biogenic particles increased. In the marine part of the marginal filter (stations 11, 12), more than $70 \%$ of particles were of biogenic origin. The same tendency was described earlier in the Siberian Arctic estuaries and deltas (Shevchenko et al., 1996; Cauwet and Sidorov, 1996; Lukashin et al., 1999; Dittmar and Kattner, 2003). This is explained by sedimentation of riverine organic and mineral particles as a result of flocculation and coagulation at the river-sea interface and the production of biogenic suspended matter (phytoplankton) in the marine zone, resulting in an increase in percentage of organic carbon in suspended particulate matter.

$\mathrm{POC} / \mathrm{PON}$ ratio $\left(\mathrm{C}_{\text {org }} / \mathrm{N}\right.$ ratio in suspended particulate matter) in river mouth (St. 25) was 8.5, decreasing to 8.1 in the transitional zone and to 6.1 in marine zone (Fig. 5). A similar decrease of $\mathrm{C}_{\text {org }} / \mathrm{N}$ ratio from the river to the open sea was found in the Keret' estuary (northern part of Karelia) in September 2000 (Dolotov et al., 2002b). For the marine and fresh-water phytoplankton, the $\mathrm{C}_{\mathrm{org}} / \mathrm{N}$ ratio is close to 7 (Redfield et al., 1963; Lerman et al., 1995), whereas for terrigenic organic matter (soil-derived material, terrestrial plant fibers, reworked peat) it can exceed 20 (Bordowskiy, 
Table 2. Concentrations of particulate organic carbon $(\mu \mathrm{g} / \mathrm{l})$ and its contents in particulate matter $(\%)$ in marginal filters of Kem' and some other rivers.

\begin{tabular}{|c|c|c|c|c|c|c|}
\hline \multirow{2}{*}{ River } & \multirow{2}{*}{ Time } & \multicolumn{2}{|c|}{ In rivers } & \multicolumn{2}{|c|}{ In adjacent sea } & \multirow{2}{*}{ Reference } \\
\hline & & $\mu \mathrm{g} / \mathrm{l}$ & $\%$ & $\mu \mathrm{g} / \mathrm{l}$ & $\%$ & \\
\hline \multicolumn{7}{|c|}{ The White Sea } \\
\hline Kem' & Beginning of July 2001 & 404 & 5.64 & $132-274$ & $19-52.6$ & This work \\
\hline \multirow{2}{*}{ Northern Dvina } & Average annual & 2600 & 6.4 & & & Artemyev and Romankevich (1988) \\
\hline & Summer 1995 & $500-700$ & 6.0 & & & Koukina et al. (2001) \\
\hline Niva & June 2000 & 629 & 43.4 & 268 & 10.2 & Lukashin et al. (2003a) \\
\hline Kolvitza & June 2000 & 213 & 81.9 & 196 & 42.6 & Lukashin et al. (2003a) \\
\hline Knyazhaya & June 2000 & 215 & 37.1 & 190 & 46.3 & Lukashin et al. (2003a) \\
\hline \multicolumn{7}{|c|}{ The Kara and Laptev seas } \\
\hline \multirow{2}{*}{$\mathrm{Ob}$} & September 1993 & $490-4110$ & $4.1-10.8$ & $100-157$ & $21.7-26.6$ & Shevchenko et al. (1996) \\
\hline & September 1997 & $404-893$ & $8.7-12.1$ & $185-219$ & $26.0-29.1$ & Lukashin et al. (1999) \\
\hline \multirow{2}{*}{ Yenisey } & September 1993 & $234-820$ & $4.9-21.4$ & $91-105$ & $32.5-40.8$ & Shevchenko et al., 1996 \\
\hline & September 1997 & $221-248$ & $5.6-6.2$ & $265-294$ & $19.6-26.1$ & Lukashin et al. (1999) \\
\hline \multirow[t]{2}{*}{ Lena } & September 1989 and 1991 & $860-1430$ & $3.1-4.3$ & $<120$ & 20 & Cauwet and Sidorov (1996) \\
\hline & July 1994 and 1995 & $628-1575$ & $3.7-11.6$ & & & Rachold and Hubberten (1999) \\
\hline
\end{tabular}

1965; Scheffer and Schachtschnabel, 1984). In the Kem' marginal filter, this tendency is not so strong, because the role of marine phytoplankton in the composition of SPM in the Kem' mouth is high and the input of terrigenic refractory organic matter is low due to reduced fluvial inputs in summer (Leonov and Chicherina, 2004). This situation is different from Siberian rivers, where significant quantities of POC are discharged into their estuaries and is comprised primarily of refractory compounds derived from vascular plant detritus. Also, the phytoplankton and living bacterial biomass is low in all high Arctic rivers (Cauwet and Sidorov, 1996; Sorokin and Sorokin, 1996; Lobbes et al., 2000; Dittmar and Kattner, 2003). The POC/PON ratio is 11 on average for the Russian Arctic rivers (Lobbes et al., 2000).

At the beginning of July 2001, phytoplankton was studied in the section from the river (St. 25) to the strait of Kemskaya Salma (St. 16 and 15) and to the shallow sea water (St. 11 and 12). During this expedition, 65 species of phytoplankton (12 freshwater species and 53 marine species) were found in the study area. Diatoms (37 species) and peridinea (8 species) dominated the total number of species. Maximal biomass of phytoplankton in this section (400-800 $\mathrm{mg} \mathrm{C} \mathrm{m}^{-3}$ ) was registered at St. 25 in the river, at Station 15 in the intermediate zone in Kemskaya Salma and at St. 12 in the shallow marine waters (Fig. 6). The composition of phytoplankton was typical for summer season in the White Sea (Khlebovich, 1974; Rat'kova, 2000; Berger et al., 2001; Il'yash et al., 2003). Maximal biomasses of diatoms were found at stations 25 (in the river) and 15 (in the Kemskaya Salma strait). Prymnesiophyte Phaeocystis pouchetii and other primnesiophytes were abundant both in the river (St. 25) and in the marine zone. The marine phytoplankton dominated in biomass at all stations, including St. 25.
At the end of August 2002, 113 species of phytoplankton (8 freshwater species and 105 marine species) were found in the study area. Diatoms (76 species) and peridinea (20 species) dominated the total number of species. Thus, the phytoplankton of studied area were characterized as marine with some influence of fresh-water species (Il'yash et al., 2003). Species composition (Table 3) illustrates the transition in communities between summer and autumn: there are both diatoms preferring warm conditions (Skeletonema costatum) and those preferring cold water conditions (Thalassiosira nordenskioeldii).

The phytoplankton biomass in the surface layer at St. 23 in river mouth was $30.2 \mathrm{mg} \mathrm{C} \mathrm{m}^{-3}$. In the intermediate zone at St. 15 it was much lower $\left(3.88 \mathrm{mg} \mathrm{C} \mathrm{m}^{-3}\right)$, and in the marine zone (St. 39) it increased to $5.16 \mathrm{mg} \mathrm{C} \mathrm{m}^{-3}$. In phytoplankton the role of fresh-water species decreases and role of marine species increases from the river to sea (Fig. 6). At St. 23, species diversity was low (19 species, 5 of them are freshwater species). Freshwater cyanobacteria Woronichinia naegeliana and diatom Detonula confervacea dominated, diatoms Paralia sulcata, Skeletonema costatum and Rhizosolenia hebetata were subdominant here.

At Station 15 in the intermediate zone (water depth is $11 \mathrm{~m}) 32$ species of phytoplankton were found. Diatoms $S$. costatum and Thalassiosira nordenskioeldii dominated and Cylindrotheca closterium and $R$. hebetata were subdominant. At this station phytoplankton mainly was concentrated in the upper $2 \mathrm{~m}$ of the water column. In this layer brackish- and freshwater diatoms Melosira numiloides, Paralia sulcata, Diatoma elongatum and freshwater cyanobacteria W. naegeliana and Microcystis aeruginosa were common. Deeper (at $5 \mathrm{~m}$ and $10 \mathrm{~m}$ ) the phytoplankton consists mostly of marine diatoms (both living cells of Chaeto- 


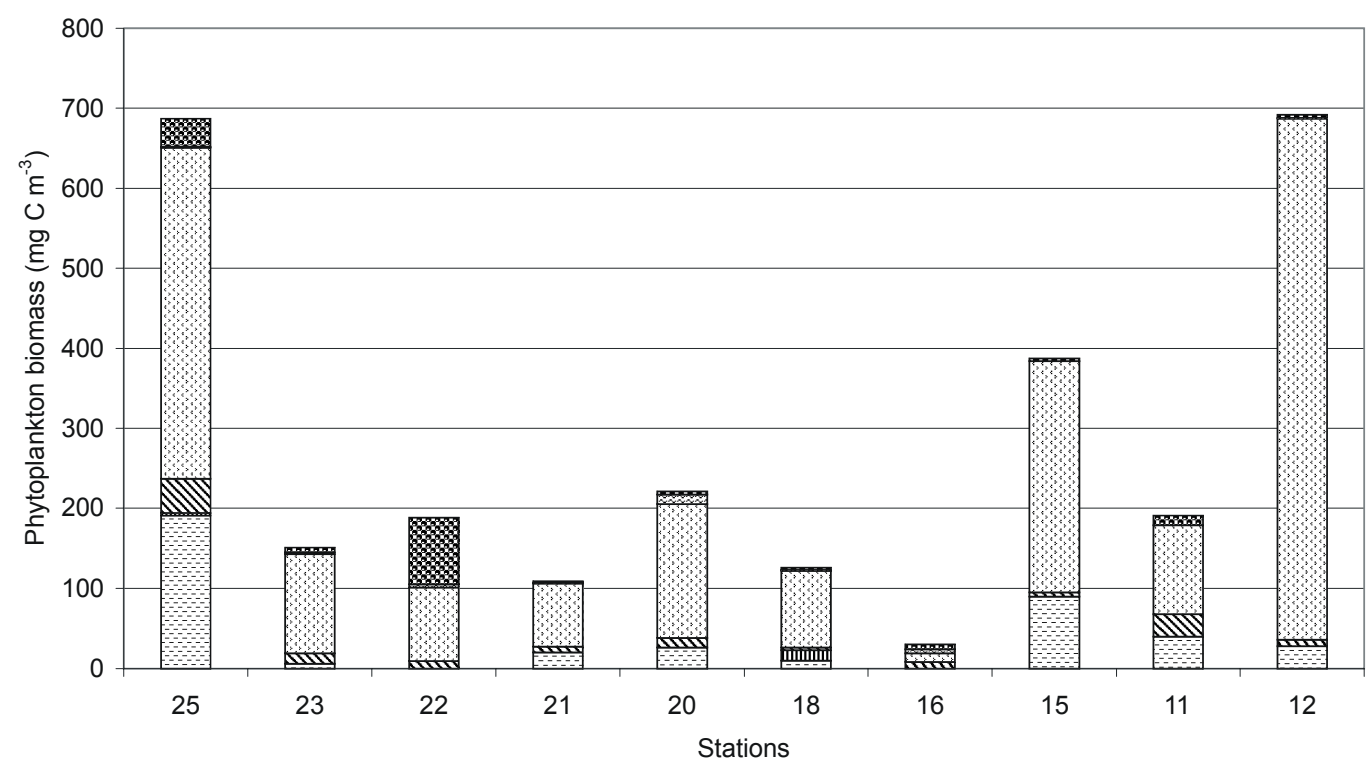

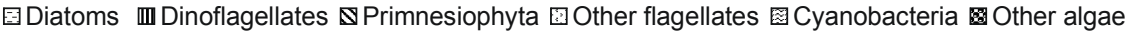

Fig. 6. Phytoplankton biomass at the section river-sea in the beginning of July 2001.

Table 3. Composition of leading complex of phytoplankton in Kem' marginal filter at the end of August 2002.

\begin{tabular}{lcl}
\hline Station 23 & Station 15 & Station 39 \\
\hline \multicolumn{3}{c}{ Dominants } \\
\hline $\begin{array}{l}\text { Woronichinia naegeliana } \\
\text { Detonula confervacea }\end{array}$ & $\begin{array}{l}\text { Skeletonema costatum } \\
\text { Thalassiosira nordenskioeldii }\end{array}$ & $\begin{array}{l}\text { Skeletonema costatum } \\
\text { Thalassiosira nordenskioeldii }\end{array}$ \\
\hline \multicolumn{3}{c}{ Subdominants } \\
\hline $\begin{array}{l}\text { Skeletonema costatum } \\
\text { Paralia sulcata } \\
\text { Rhizosolenia hebetata }\end{array}$ & Cylindrotheca closterium & $\begin{array}{l}\text { Cylindrotheca closterium } \\
\text { Rhizosolenia hebetata } \\
\text { Rhizosolenia hebetata }\end{array}$ \\
\hline
\end{tabular}

ceros subtilis, Rhizosolenia hebetata, Coscinodiscus radiatus, Pleurosigma stuxbergii and spores of Melosira arctica and Thalassiosira nordenskioeldii). In the near-bottom layer 5 species of lithoral-benthic diatom and empty valves of ice diatoms Achnanthes taeniata and Fragilariopsis oceanica were found. Possibly, they were resuspended from bottom sediments by near-bottom tidal currents.

At Station 39 in the marine zone, 72 species of diatoms and 17 species of peridinea were identified. Diatoms $S$. costatum and Th. nordenskioeldii were dominants and S. costatum, Th. nordenskioeldii, Thalassionema nitzschioides - subdominants. Phytoplankton were more abundant in the upper $10 \mathrm{~m}$ layer over the picnocline and in the near-bottom layer. The lithoral-benthic species of diatoms dominated in the nearbottom layer. There were 19 species of lithoral-benthic diatom species from the genera Navicula, Amphora, Diploneis, Cocconeis, Synedra. In general, in seaward direction per- centage of cyanobacteria decreases and the role of diatoms increases, the percentage of small flagellates has no trend (Fig. 8). Bottom sediments in the estuary and the adjacent part of the White Sea (Table 1) were mostly coarse grained (aleurities, sands, with inclusion of gravel, broken and well preserved shells of Mytilus edulis and other bivalvia mollusks). In general, the grain size distribution here did not depend on the water depth as it was found in many other regions of the Ocean (Lisitzin, 1996). The main reason is the complex hydrodynamic situation in the studied area, which is determined by the shallow waters (not deeper than $29 \mathrm{~m}$ ), tidal activity and the influence of large number of small islands (Nevessky et al., 1977). Ice can contribute significantly to the modern sedimentation in the Kem' estuary. The Kem' estuary and the adjacent Onega Bay are situated in cold climate conditions. Ice formation begins here in November and ice breaks in May (Glukhovsky, 1991). Ice can affect the 


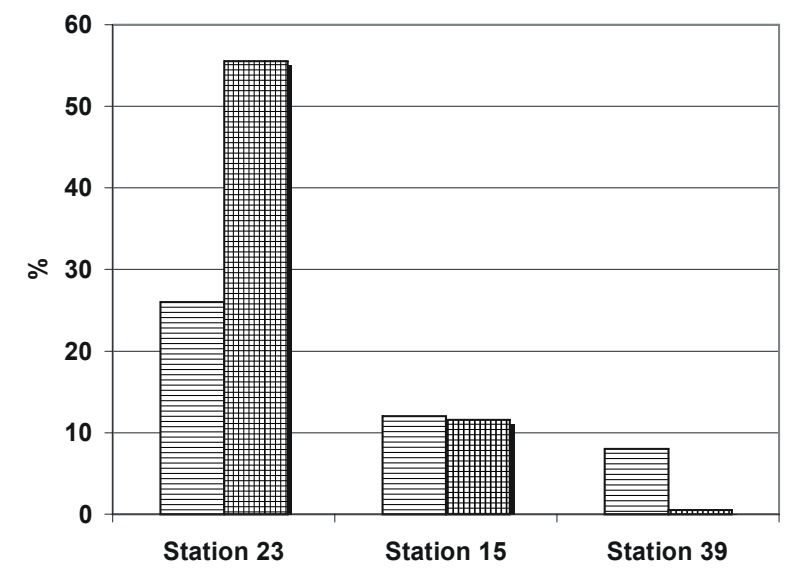

目 $\%$ of fresh-water species 囲\% of fresh-water species biomass

Fig. 7. Percentage of fresh-water species in total number of species and biomass of phytoplankton at the end of August 2002.

distribution of sediment texture and carbon. The great role of ice in modern geological processes is described in many other polar areas (Lisitzin, 2002), but in the Kem' estuary it has not been studied.

Organic carbon $\left(\mathrm{C}_{\mathrm{org}}\right)$ content of sandy bottom sediments in the Kem' river (St. 25$)$ is low $(0.13 \%)$. It is also low in sands from intermediate and marine zones (stations 11, 111 and 118). The maximum $\mathrm{C}_{\text {org }}$ contents was registered in the pelitic and aleuro-pelitic sediments at stations 1, 5, 113, 128. In the marine part of the mixing zone it is higher (up to $2.04 \%$ ). The correlation coefficient between the $\mathrm{C}_{\text {org }}$ content and the fraction $<50 \mu \mathrm{m}$ is 0.78 for 17 samples (Fig. 9). The correlation is significant at the level of $99 \%(\alpha=0.01)$. The same dependence of the $\mathrm{C}_{\text {org }}$ contents from granulometry is typical for bottom sediments, especially in shelf seas (Nevessky et al., 1977; Romankevich, 1984; Romankevich and Vetrov, 2001; Stein and Macdonald, 2003) and could be explained by the fine grain sizes of most part of organic matter, $\mathrm{C}_{\text {org }}$ adsorption to clay minerals and hydrodynamical and lithodynamical regularities of particle transport.

The $\mathrm{C}_{\text {org }} / \mathrm{N}$ ratio in bottom sediments decreases from 14.6 in the river to 4.6-8.4 in marine part of the mixing zone (Fig. 5), demonstrating that content of terrestrially-derived organic matter decreases and content of marine organic matter increases from the river mouth to the sea. A similar decrease of $\mathrm{C}_{\mathrm{org}} / \mathrm{N}$ ratio in bottom sediments from the river to sea was found in marginal filters of Siberian rivers (Stein, 1996; Boucsein et al., 1999; Fahl et al., 2003; Stein and Macdonald, 2003).

The $\mathrm{C}_{\text {org }} / \mathrm{N}$ ratio in the bottom sediments of Kem' mouth is significantly higher than the POC/PON in suspended matter at this station. This difference exists because suspended matter was collected during the seasonal lows in interflow, when input of terrigenous organic matter is minimal and marine and brackish-water phytoplankton may be delivered to

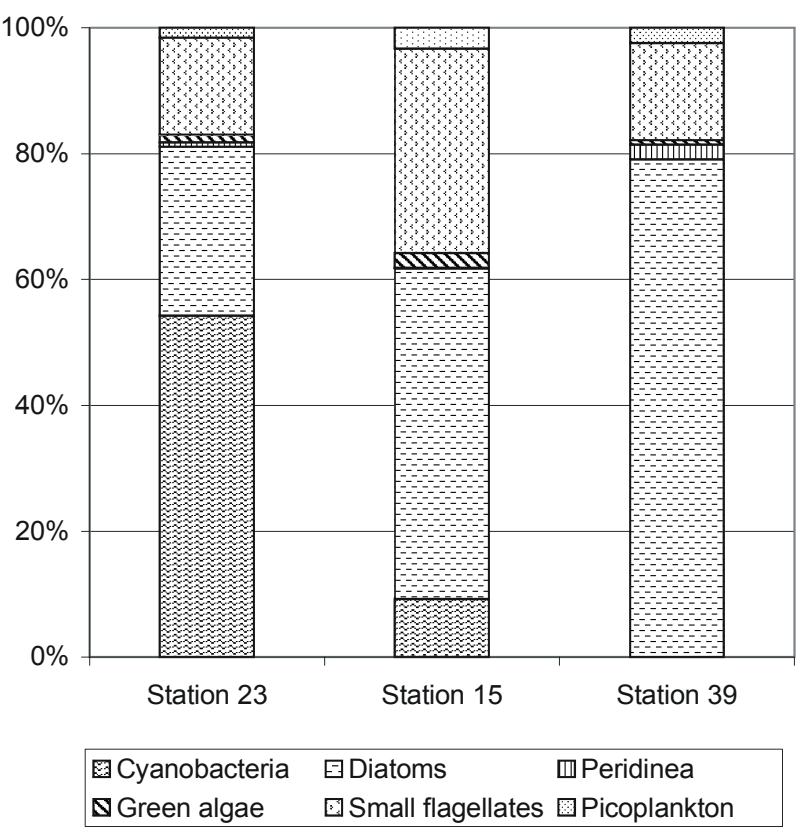

Fig. 8. Percentage of different phytoplankton groups in total biomass at the end of August 2002.

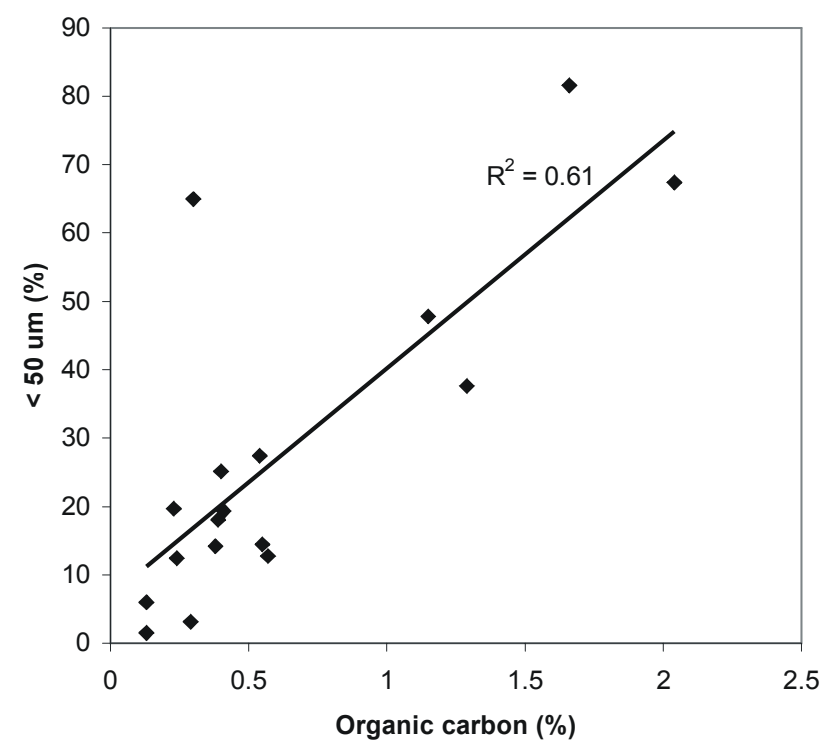

Fig. 9. Correlation between total organic carbon content (\%) and percentage of fine fraction $<50 \mu \mathrm{m}$ in surface sediments from the Kem' marginal filter.

the upper part of the Kem' estuary by tide. Otherwise, the majority of the terrigenic refractory particulate organic matter is accumulated in the marginal filter during the spring flood, when during May and June in the White Sea more than half of annual water and suspended load is discharged (Maximova, 1991; Gordeev et al., 1996; Berger et al., 2001; Leonov and Chicherina, 2004). 


\section{Conclusions}

The majority of the suspended matter in the Kem' estuary deposits near the river mouth in the marginal filter area within the 20 psu isohaline, where rapid sedimentation of the suspended matter takes place.

In phytoplankton populations the role of fresh-water species decreases and the role of marine species increases from the river to sea. In this direction the percentage of green algae decreases and the role of diatoms increases.

$\mathrm{C}_{\text {org }} / \mathrm{N}$ ratio in both suspended matter and bottom sediments decreases from river to the marine part of the mixing zone, demonstrating that the content of terrestrial-derived organic matter decreases and content of marine organic matter increases in the direction from the river mouth to the sea.

The Kem' estuary demonstrates a similar range of biogeochemial processes as in the large Arctic estuaries, but the scale of these processes (amount of river input of SPM, POC, area of estuaries) is different.

Acknowledgements. We thank crew of the research vessel "Ekolog", V. N. Kovalenko, N. V. Denisenko, P. M. Boyarinov, A. V. Mitrokhov, M. P. Petrov, A. V. Tolstikov for help in expeditions and Ya. N. Yanina for the graphics. The authors are indebted to Academician A. P. Lisitzin for valuable recommendations and to K. V. Filippieva, R. Frohlking, V. P. Kazakova, Ch. Lorenzen and A. N. Rudakova for assistants in analyses. We also thank two anonymous reviewers for their constructive suggestions for the improvement of the manuscript. Our studies were financially supported by Russian Fund of Basic Research (grants 03-05-64079 and 05-05-65159), INCO-COPERNICUS (grants ICA2-CT-200010053 and ICA2-CT-2000-10014), Russian Federal Program "The World Ocean", Presidium of the Russian Academy of Sciences (projects 4.5 and "Nanoparticles in the Earth's spheres"), grant NSh-1940.2003.5 of the President of Russia, Russian-German Otto Schmidt Laboratory.

Edited by: A. Reeves

\section{References}

Artemyev, V. E. and Romankevich, E. A.: Seasonal variations in the transport of organic matter in North Dvina estuary, in: Transport of carbon and minerals in major world rivers, edited by: Degens, E. T., Kempe, S., and Naidu, A. S., Mitt. Geol.-Paläont. Inst. Univ. Hamburg, SCOPE/UNEP Sonderband, 66, Pt. 5, Hamburg, pp. 177-184, 1988.

Berger, V., Dahle, S., Galaktionov, K., Kosobokova, X., Naumov, A., Rat'kova, T., Savinov, V., Savinova, T.: White Sea. Ecology and environment, St.-Petersburg - Troms $\varnothing$ : Derzaveters Publishers, 157 pp., 2001.

Bordowskiy, O. K.: Sources of organic matter in marine basins, Mar. Geol., 3, 5-31, 1965.

Boucsein, B., Fahl, K., Siebold, M., and Stein, R.: Quantity and quality of organic carbon in surface sediments of the $\mathrm{Ob}$ and Yenisei estuaries, Reports on Polar Research, 300, 116-126, 1999.
Cauwet, G. and Sidorov, I. S.: The biogeochemistry of the Lena River: organic carbon and nutrient distribution, Mar. Chem., 53, 211-227, 1996.

Dittmar, T. and Kattner, G.: The biogeochemistry of the river and shelf ecosystem of the Arctic Ocean: a review, Mar. Chem., 83, 103-120, 2003.

Dolotov, Yu. S., Filatov, N. N., Nemova, N. N., Shevchenko, V. P., Rimskii-Korsakov, N. A., Denisenko, N. V., Kutcheva, I. P., Platonov, A. V., Demina, L. L., Zdorovennov, R. E., and Kovalenko, V. N.: Studies of the water and suspended matter dynamics, anthropogenic pollution, and ecosystem living conditions in the estuaries (from the example of the Karelian coast of the White Sea), Oceanology, 42, Suppl. I: S135-S147, 2002a.

Dolotov, Yu. S., Filatov, N. N., Shevchenko, V. P., Nemova, N. N., Rimskii-Korsakov, N. A., Denisenko, N. V., Kutcheva, I. P., Boyarinov, P. M., Petrov, M. P., Lifshitz, V. Kh., et al.: Monitoring of tidal environment in estuaries of the Karelian coast of the White Sea, Water Resources, 32 (in Russian; in press), 2005.

Dolotov, Yu. S., Filatov, N. N., Shevchenko, V. P., Petrov, M. P., Kutcheva, I. P., Tolstikov, A. V., Novigatsky, A. N., Politova, N. V., Platonov, A. V. and Filippov, A. S.: On the character of natural processes at high and low tides in the estuaries of the Karelian coast of the White Sea, Oceanology, 44, 784-792, 2004.

Dolotov, Yu. S., Kovalenko, V. N., Lifshits, V. Kh., Petrov, M. P., Platonov, A. V., Prego, R., Rat'kova, T. N., Filatov, N. N., and Shevchenko, V. P.: On the dynamics of water and suspension in the Keret' River estuary (the Karelian coast of the White Sea), Oceanology, 42, 731-740, 2002b.

Fahl, K., Stein, R., Gaye-Haake, B., Gebhardt, C., Kodina, L. A., Unger, D., and Ittekkot, V.: Biomarkers in surface sediments from the $\mathrm{Ob}$ and Yenisei estuaries and the southern Kara Sea: Evidence for particulate organic carbon sources, pathways, and degradation, in: Siberian river run-off in the Kara Sea, edited by: Stein, R., Fahl, K., Fuetterer, D. K., Galimov, E. M., and Stepanets, O. V., Elsevier Science, pp. 329-348, 2003.

Fichez, R., Dennis, P., Fontaine, M. F., and Jickells, T. D.: Isotopic and biochemical composition of particulate organic matter in a shallow water estuary (Great Ouse, North Sea, England), Mar. Chem., 43, 263-276, 1993.

Gebhardt, A. C., Gaye-Haake, B., Unger, D., Lahajnar, N., and Ittekkot, V.: Recent particulate organic carbon and total suspended matter fluxes from the $\mathrm{Ob}$ and Yenisei Rivers into the Kara Sea (Siberia), Mar. Geol., 207, 225-245, 2004.

Glukhovsky, B. H. (Ed.): Hydrometeorology and Hydrochemistry of USSR Seas, 2. The White Sea, part 1, 240 pp., 1991.

Gordeev, V. V., Martin, J.-M., Sidorov, I. S., and Sidorova, M. V.: A reassessment of the Eurasian river input of water, sediment, major elements, and nutrients to the Arctic Ocean, Amer. J. Sci., 296, 664-691, 1996.

IASC Project Catalogue: IASC Secretariat, Oslo, 69 pp., 2004.

Il'yash, L. V., Zhitina, L. S., and Fedorov, V. D.: The White Sea Phytoplankton, Moscow, Yanus-K, 168 p., 2003.

Joint, I. R. and Pomroy, A. J.: Primary production in a turbid estuary, Estuarine, Coastal and Shelf Science, 13, 303-316, 1981.

Kemp, P., Wetzel, R. L., Boynton, W. R., D'Elia, C. F., and Stevenson, J. C.: Nitrogen cycling and estuarine interfaces: some current concepts and research directions, in: Estuarine Comparisons, edited by: Kennedy, V. S., Academic, New York, pp. 209230, 1982. 
Khlebovich, T. V.: Qualitative composition and seasonal chages of quantity of phytoplankton in the Chupa Bay of the White Sea, in: Seasonal phenomena in the life of the White and Barents seas, Leningrad, Nauka, pp. 56-64 (in Russian), 1974.

Khlebovich, V. V., Ivanov, V. V., and Makeyev V. M.: Assessment aspect of contamination of the Arctic estuary ecosystems, Marine Pollution Bulletin, 35, 222-225, 1997.

Koukina, S. E., Calafat-Frau, C., Hummel, H., and Palerud, R.: Trace metals in suspended particulate matter and sediments from the Severnaya Dvina estuary, Russian Arctic, Polar Record, 37 (202), 249-256, 2001.

Leonov, A. V. and Chicherina, O. V.: Nutrient transport into the White Sea with river runoff, Water Resources, 31, 152-173, 2004.

Lerman, A., Imboden, D., and Gat, J.: Physics and Chemistry of Lakes, Springer, Berlin, 334 pp., 1995.

Lisitsyn, A. P.: The marginal filter of the ocean, Oceanology, 34, 671-682, 1995.

Lisitsyn, A. P., Shevchenko, V. P., and Burenkov, V. I.: Hydrooptics and suspended matter of the Arctic seas, Atmospheric and Oceanic Optics, 13, 61-71, 2000.

Lisitzin, A. P.: Oceanic Sedimentation. Lithology and Geochemistry, American Geophysical Union, Washington, D.C., 400 pp., 1996.

Lisitzin, A. P.: Sea-ice and Iceberg Sedimentation in the Ocean: Recent and Past, Berlin, Heidelberg: Springer-Verlag, 563 pp., 2002.

Lisitzin, A. P.: New possibilities of four-dimentional oceanology and the monitoring of second generation - experience of twoyear studies in the White Sea, in: Actual Problems of Oceanology, edited by: Laverov, N. P., Vinogradov, M. E., Lisitzin, A. P., Lappo, S. S., and Lobkovsky, L. I., Moscow: Nauka, pp. 501554 (in Russian), 2003.

Lisitzin, A. P., Shevchenko, V. P., Burenkov, V. I., Kopelevich, O. V., and Vasiliev, L. Yu.: Suspended matter and hydrooptics of the White Sea - new regularities of quantitative distribution and granulometry, in: Actual Problems of Oceanology, edited by: Laverov, N. P., Vinogradov, M. E., Lisitzin, A. P., Lappo, S. S., and Lobkovsky, L. I., Moscow: Nauka., pp. 554-605 (in Russian), 2003.

Lisitzin, A. P., Shevchenko, V. P., and Gordeev, V. V.: Multidisciplinary studies in the White Sea in the frame of the LOIRA project, Reports on Polar and Marine Research, 482, 124-130, 2004.

Lobbes, J., Fitznar, H. P., and Kattner, G.: Biogeochemical characteristics of dissolved and particulate organic matter in Russian rivers entering the Arctic Ocean, Geochim. Cosmochim. Acta, 64, 2973-2983, 2000.

Lukashin, V. N., Isaeva, A. B., Rat'kova, T. N., and Prego, R.: Particulate matter and vertical particle fluxes in the White Sea, Oceanology, 43, Suppl. 1, S159-S172, 2003a.

Lukashin, V. N., Ljutsarev, S. V., Krasnyuk, A. D., Shevchenko, V. P., and Rusakov, V. Yu.: Suspended particulate matter in the $\mathrm{Ob}$ and Yenisei estuaries, Reports on Polar Research, 300, 155-178, 1999.

Lukashin, V. N., Kosobokova, K. N., Shevchenko, V. P., Shapiro, G. I., Pantiulin, A. N., Pertzova, N. M., Deev, M. G., Klyuvitkin, A. A., Novigatsky, A. N., Soloviev, K. A., Prego, R., and Lache, L.: Results of complex oceanographic studies in the White Sea in June 2000, Oceanology, 43, 237-253, 2003b.

Martin, J.-M., Guan, D. M., Elbaz-Poulichet, F., Thomas, A. J., and Gordeev, V. V.: Preliminary assessment of the distributions of some trace elements ( $\mathrm{As}, \mathrm{Cd}, \mathrm{Cu}, \mathrm{Fe}, \mathrm{Ni}, \mathrm{Pb}$ and $\mathrm{Zn}$ ) in a pristine aquatic environment: the Lena River Estuary (Russia), Mar. Chem., 43, 185-199, 1993.

Martin, J.-M. and Windom, H. L.: Present and future roles of ocean margins in regulating marine biogeochemical cycles of trace elements, in: Ocean Margin Processes in Global Change, edited by: Mantoura, R. F. C., Martin, J.-M., and Wollast, R., Wiley, Chichester, pp. 45-67, 1991.

Maximova, M. P.: Hydrochemistry of the White Sea, in: Hydrometeorology and Hydrochemistry of USSR Seas, 2. The White Sea, part 2, pp. 8-193, 1991.

Menden-Deuer, S. and Lessard, E. J.: Carbon to volume relationship for dinoflagellates, diatoms and other protists plankton, Limnology and Oceanography, 45, 569-579, 2000.

Nemkovich, E. G. and Katmazin, A. S. (Eds.): Karelia. Petrozavodsk: Karelia, 197 pp. (in Russian), 1999.

Nevessky, E. N., Medvedev, V. S., and Kalinenko, V. V.: The White Sea, Sedimentogenesis and the history of the development during the Holocene, Moscow, Nauka, 235 pp. (in Russian), 1977.

Parshina, L. N.: Weather in the Russian Federation in July 2003, Meteorology and Hydrology, No. 10, 113-116 (in Russian), 2003.

Petelin, V. P.: Grain-size analysis of marine bottom sediments, Moscow, Nauka, 128 pp. (in Russian), 1967.

Rachold, V. and Hubberten, H.-W.: Carbon isotope composition of particulate organic material in East Siberian rivers, in: LandOcean Systems in the Siberian Arctic, Dynamics and History, edited by: Kassens, H., Bauch, H. A., Dmitrenko, I. A., et al., Springer, pp. 223-238., 1999.

Rat'kova, T. N.: Phytoplankton composition in the White Sea Basin in summer - autumn 1998 and 1999, Reports on Polar Research, 359, 97-109, 2000.

Redfield, A. C., Ketchum, B. H., and Richards, F. A.: The influence of organisms on the composition of sea water, in: The Sea, edited by: Hill , M. N., New York, Wiley, pp. 26-77, 1963.

Relexans, J. C., Meybeck, M., Billen, G., Brugeaille, M., Etcheber, H., and Somville, M.: Algal and microbial processes involved in particulate organic matter dynamics in the Loire (France), Oceanol. Acta, 7, 191-207, 1988.

Romankevich, E. A.: Geochemistry of Organic Matter in the Ocean, Springer, Heidelberg, 334 pp., 1984.

Romankevich, E. A. and Vetrov, A. A.: Cycle of Organic Carbon in the Arctic seas of Russia, Moscow, Nauka, 300 pp. (in Russian), 2001.

Rousseau, V., Mathot, S., and Lancelot, C.: Calculating carbon biovolume of Phaeocystis sp. from microscopic observations, Marine Biology, 107, 305-314, 1990.

Schäfer, J., Blanc, G., Lapaquellerie, Y., Maillet, N., Maneux, E., and Etcheber, H.: Ten-year observation of the Gironde tributary fluvial system: fluxes of suspended matter, particulate organic carbon and cadmium, Mar. Chem., 79, 229-242, 2002.

Scheffer, F. and Schachtschnabel, P.: Lehrbuch der Bodenkunde, Stuttgart, Enke, 442 pp., 1984.

Shevchenko, V. P., Severina, O. V., Mayorova, N. G., and Ivanov, G. V.: Quantitative distribution and composition of suspended particulate matter in $\mathrm{Ob}$ and Yenisey estuaries, Vestnik 
Moskovskogo Universiteta, 3, 81-86 (in Russian), 1996.

Sholkovitz, E. R.: Flocculation of dissolved organic and inorganic matter during the mixing of river water and seawater, Geochimica et Cosmochimica Acta, 40, 831-845, 1976.

Smayda, T. J.: From phytoplankters to biovolume, in: Phytoplankton manual, edited by: Sournia, A., UNESCO, Paris, pp. 273279, 1978.

Sorokin, Y. I. and Sorokin, P. Y.: Plankton and primary production in the Lena River estuary and in the south-eastern Laptev Sea, Estuar. Coast. Shelf Sci., 43, 399-418, 1996.

Stein, R.: Organic-carbon and carbonate distribution in surface sediments from the Eastern Central Arctic Ocean and the Eurasian continental margin: Sources and pathways, Reports on Polar Research, 212, 243-267, 1996.
Stein, R. and Macdonald, R. W. (Eds.): The Organic Carbon Cycle in the Arctic Ocean, Springer Verlag, Berlin, 363 pp., 2003.

Sviridenko, L. P.: Origin of granites and problems of Precambrian Earth's crust formation (at the example of Karelia), Leningrad, Nauka, 216 pp. (in Russian), 1980.

Vodogretzkii, V. E. (Ed.): Resources of surface waters of the USSR. V. 2. Karelia and North-West, Part 1. Leningrad: Hydrometeoizdat, 327 pp. (in Russian), 1972.

Volodichev, O. I.: Belomorsky complex of Karelia (geology and petrology), Leningrad, Nauka, 248 pp. (in Russian), 1990.

Zakharenkova, V. I. and Parshina, L. N.: Weather on the Russian Federation Territory in August 2003, Meteorology and Hydrology, 11, 109-112 (in Russian), 2003. 